\title{
Hubungan antara Lama Puasa Preanestesi dan Kadar Gula Darah Saat Induksi pada Pasien Pediatrik yang Menjalani Operasi Elektif
}

\author{
Arsy Felicita Dausawati, ${ }^{1}$ Doddy Tavianto, ${ }^{2}$ Rudi K. Kadarsah ${ }^{2}$ \\ ${ }^{1}$ Rumah Sakit Sungai Dareh Kab. Dharmasraya, ${ }^{2}$ Departemen Anestesiologi dan Terapi Intensif \\ Fakultas Kedokteran Universitas Padjadjaran/Rumah Sakit Dr. Hasan Sadikin Bandung
}

\begin{abstract}
Abstrak
Puasa preoperatif adalah untuk mengurangi volume, tingkat keasaman lambung, dan mengurangi risiko aspirasi paru. Puasa preoperatif sering kali lebih lama daripada yang direkomendasikan karena berbagai alasan di Rumah Sakit Dr. Hasan Sadikin Bandung. Tujuan penelitian ini adalah mengetahui korelasi antara lama puasa preanestesi dan kadar gula darah saat induksi pada pasien pediatrik di Rumah Sakit Dr. Hasan Sadikin Bandung. Penelitian analitik observasional cros sectional dilakukan pada pasien pediatrik pada bulan Januari-Februari 2015 di Instalasi Bedah Sentral Rumah Sakit Dr. Hasan Sadikin Bandung. Uji distribusi data menurut Kolmogorov-Smirnov kemudian dilakukan Uji kolerasi Spearman. Lama puasa minimum, maksimum, dan rata-rata (SD) puasa dari makanan 4, 15, dan 8,7500 $(3,48597)$ jam. Lama puasa minimum, maksimum, dan rata-rata (SD) dari minuman adalah 2, 15, dan 12,56 $(3,26)$ jam. Tidak ditemukan kejadian hipoglikemia pada penelitian ini dengan gula darah sewaktu induksi terendah 59 $\mathrm{mg} / \mathrm{dL}$. Terdapat hubungan yang bermakna antara lama puasa preanestesi dengan GDS induksi $(\mathrm{p}<0,05)$. Simpulan, lama puasa preanestesi pada pasien pediatrik yang akan menjalani operasi elektif melebihi dari apa yang dianjurkan oleh ASA. Terdapat hubungan antara lama puasa preanestesi dan kadar gula darah saat induksi.
\end{abstract}

Kata kunci: Kadar gula darah, lama puasa preanestesi, operasi elektif, pediatrik

\section{Correlation between Preanesthetic Fasting Duration and Blood Glucose Level During Induction in Pediatric Elective Surgery Patients}

\begin{abstract}
Preoperative fasting is to reduce the volume and acidity of gastric and further reduce the risk of pulmonary aspiration. Preoperative fasting period often longer than the recommended time for various reasons in Dr. Hasan Sadikin General Hospital Bandung. The purpose of this study was to determine the correlation between preanesthetic fasting duration and blood sugar level induction in pediatric patients in Dr. Hasan Sadikin General Hospital Bandung. An analytical observational cross-sectional study was conducted on pediatric patients during period of January-Februari 2015 at the Central Surgical Installation of Dr. Hasan Sadikin General Hospital Bandung. The minimum, maximum, and mean (SD) fasting from food duration were 4,15 , and 8.7500 (3.48597) hours. The minimum, maximum, and mean (SD) fasting from drinks durations were 2,15 and 12.56 (3.26) hours. The incidence of hypoglycemia was not found in this study. Based on the result of Spearman correlation test showed a statistically significant relationship between preanesthetic fasting duration and with blood glucose level during induction $(\mathrm{p}<0.05)$. In conclusion, preanesthetic fasting duration in pediatric patients who are undergoing an alective surgerybin this hospital is longer than the duration recommended by ASA. There is a correlation between the preanesthetic fasting period and blood sugar level during induction.
\end{abstract}

Key words: Blood glucose levels, duration of preanesthetic fasting, elective surgery, pediatric

Korespondensi: Arsy Felicita Dausawati, dr., SpAn, Rumah Sakit Sungai Dareh Kab. Dharmasraya, Jl. Lintas Sumatra Km. 2 Pulau punjung, Tlp 0754-40053, Faks 0754-40374, Mobile 081374042559, Email dearsy2410@gmail.com 


\section{Pendahuluan}

Tujuan puasa pra-anestesi adalah memberikan waktu cukup untuk pengosongan lambung, dan mengurangi risiko regurgitasi dan aspirasi paru dari sisa-sisa makanan. ${ }^{1}$ Sebaiknya, puasa sebelum induksi anestesia tidak menyebabkan dehidrasi, hipoglikemia, dan ketidaknyamanan pada pasien. Selama masa puasa pasien akan merasa haus, lapar, gelisah, mengantuk, pusing, mual, dan muntah. ${ }^{2}$ Pemanjangan waktu puasa sebelum pembedahan elektif tidak hanya dapat menyebabkan ketidaknyamanan pada pasien, tetapi juga dapat mengakibatkan efek yang merugikan seperti dehidrasi, hipoglikemia, dan hipovolemia. ${ }^{1,3}$

Berbeda dengan orang dewasa yang dapat menoleransi puasa dengan tetap pemeliharaan normoglikemia, neonatus normal dan anak kecil menunjukkan penurunan kadar glukosa darah setelah 8 jam berpuasa. ${ }^{4}$ Pada anak, cadangan glikogen dapat memberikan asupan glukosa untuk waktu 12 jam atau lebih tanpa masukan kalori. ${ }^{5}$ Setelah melewati periode ini, pemeliharaan normoglikemia pada anak akan bergantung pada glukoneogenesis. Namun, anak memiliki jaringan adiposa dan juga massa protein yang relatif rendah dibanding dengan total massa tubuh sehingga berpotensi terjadi penurunan kemampuan glukoneogenesis bila dibanding dengan orang dewasa. ${ }^{1}$

Bayi normal dan anak dengan kebutuhan glukosa yang tinggi disertai dengan gangguan glukoneogenik, berada dalam keadaan sulit untuk pemeliharaan keseimbangan glukosa. Setiap faktor yang meningkatkan kebutuhan metabolik, seperti stres/demam, penurunan asupan glukosa, ataupun perubahan kontrol endokrin akan dapat memicu hipoglikemia. ${ }^{1}$ Hipoglikemia merupakan hal yang berbahaya pada anak selama perioperatif karena dapat menyebabkan letargi, iritabilitas, dan asidosis metabolik yang menjadi masalah anestesi termasuk mencetuskan kejang. Puasa dapat mencetuskan hipoglikemia, meskipun bukan konsekuensi dari pembatasan makan. ${ }^{4}$

Banyak kejadian pasien yang berpuasa 1216 jam yang ditemukan di berbagai institusi kesehatan. Puasa akan memanjang lebih lama ketika operasi tertunda. Penelitian di India mendapatkan data pemanjangan waktu puasa disebabkan oleh instruksi yang salah dari petugas kesehatan sebanyak $74 \%$ dan akibat diundurnya jadwal operasi sebanyak 32\%.7-9

Penelitian di Inggris terhadap 34 anak yang menjalani one day surgery (ODS) didapatkan $20 \%$ anak berpuasa hingga lebih dari 16 jam sebelum operasi serta 8,8\% anak didapatkan dalam keadaan hipoglikemia. Penelitian di Amerika Serikat pada 200 anak yang menjalani ODS didapatkan 2 kasus hipoglikemia sebelum induksi. Namun, tidak didapatkan indikator yang mudah untuk memperkirakan terjadi kasus hipoglikemia sebelum induksi. ${ }^{7,8}$ Periode puasa harus ditinjau lagi untuk menentukan keuntungan dan efek sampingnya. ${ }^{2,10}$

Penelitian di Jepang menunjukkan bahwa pemberian cairan bening per oral dua jam sebelum induksi anestesia tidak meningkatkan isi lambung, namun akan mengurangi isi dan juga keasaman lambung melalui peningkatan pengosongan lambung. Pemberian cairan yang mengandung dekstrosa 2 jam sebelum induksi dapat mengurangi kebutuhan terhadap cairan yang mengandung dekstrosa intravena dan juga dapat membantu mempertahankan kadar glukosa darah plasma normal. ${ }^{1}$

American Society of Anesthesiology (ASA) telah menerbitkan pedoman praktik tentang puasa pre-anestesi sebagai suatu upaya untuk meminimalkan kejadian aspirasi. Makanan padat dilarang dalam waktu 6 sampai 8 jam sebelum anestesia (umumnya setelah tengah malam), air susu ibu (ASI) dalam waktu 4 jam sebelum anestesia, dan cairan bening dalam waktu 2 jam sebelum anestesia. ${ }^{9}$

Tujuan penelitian ini adalah mengetahui hubungan antara lama puasa pre-anestesi dan kadar gula darah saat induksi pada pasien pediatrik di Instalasi Bedah Sentral Rumah Sakit Dr. Hasan Sadikin Bandung.

\section{Subjek dan Metode}

Penelitian ini merupakan penelitian analitik observasional crossectional yang dilakukan setelah mendapatkan persetujuan dari Komite Etik Penelitian Kesehatan Fakultas Kedokteran 
Tabel 1 Karakteristik Subjek Penelitian

\begin{tabular}{lcccc}
\hline \multicolumn{1}{c}{ Variabel } & Jumlah & Mean (SD) & Median & Range \\
\hline Laki-Laki & $26(50 \%)$ & & & \\
Perempuan & $26(50 \%)$ & & & \\
Usia (tahun) & & $3,1635(1,59878)$ & 3,0000 & 5,00 \\
Dirawat & $43(83 \%)$ & & & \\
ODS & $9(17 \%)$ & & & \\
\hline
\end{tabular}

Universitas Padjadjaran/Rumah Sakit Dr. Hasan Sadikin (RSHS) Bandung. Penelitian dilakukan pada bulan Januari sampai dengan Februari 2015 dengan kriteria inklusi adalah pasien pediatrik berusia 6 bulan sampai 6 tahun baik dirawat dan tidak dirawat (ODS) yang menjalani operasi elektif di Instalasi Bedah Sentral RSHS Bandung dengan status fisik ASA 1 atau 2. Kriteria eksklusi adalah pasien dengan penyakit metabolik dan atau dengan ibu diabetes melitus. Penentuan besar sampel menggunakan rumus untuk penelitian analitis korelatif numerik sehingga diperoleh jumlah sampel 52 orang.

Penelitian dilakukan dengan menanyakan kepada orangtua pasien mulai jam berapa berpuasa, kapan makan, dan minum terakhir, apakah pasien mendapatkan cairan intravena dan jenis cairan. Kemudian, dicatat data gula darah sewaktu terakhir, waktu mulai induksi, jarak makan dan juga minum terakhir dengan mulai induksi, serta dilakukan pemeriksaan glukosa darah sewaktu saat dilakukan induksi di kamar operasi setelah pasien tertidur.

Analisis data dilakukan menggunakan Uji Kolmogorov Smirnov dan untuk mengetahui hubungan antara lama puasa pre-anestesi dan kadar gula darah saat induksi anestesia pada pasien pediatrik di Instalasi Bedah Sentral RSHS Bandung dipergunakan Uji Spearman.

Tabel 2 Gula Darah Sewaktu (GDS) Subjek Penelitian

\begin{tabular}{lccc}
\hline \multicolumn{1}{c}{ GDS } & Mean (SD) & Median & Range \\
\hline Sebelum & 111,7692 & 110,5000 & 40,00 \\
puasa & $(9,24740)$ & & \\
Induksi & 89,2115 & 91,0000 & 63,00 \\
& $(14,95921)$ & & \\
\hline
\end{tabular}

Kriteria kemaknaan yang digunakan adalah nilai $\mathrm{p}$, nilai $\mathrm{p}<0,05$ adalah signifikan atau bermakna secara statistika. Data-data yang diperoleh dicatat di dalam formulir khusus, kemudian diolah melalui program statistical product and service solution (SPSS) versi 21.0 for Windows.

\section{Hasil}

Penelitian dilakukan pada 52 pasien pediatrik berusia enam bulan sampai enam tahun yang menjalani operasi elektif di Instalasi Bedah Sentral Rumah Sakit Dr. Hasan Sadikin selama bulan Januari-Februari 2015. Karakteristik subjek penelitian untuk jenis kelamin dari total subjek sebanyak 52 orang diketahui bahwa jenis kelamin laki-laki dan perempuan berjumlah sama banyak, yaitu 26 orang masing-masing (Tabel 1).

Hubungan antara kadar GDS saat induksi dan juga lama puasa preanestesi dianalisis menggunakan Uji Spearman serta diperoleh $\mathrm{p}=0,042$ dan bermakna secara statistika $(\mathrm{p}<0,05)$. Koefisien korelasi (R) yang diperoleh bernilai negatif yang berarti bahwa semakin lama puasa preanestesi maka akan semakin rendah kadar gula darah sewaktu (GDS) saat induksinya, dengan kekuatan korelasi yang kecil (tidak erat) antara GDS induksi dan lama puasa.

Tabel 3 Lama Puasa Subjek Penelitian

\begin{tabular}{lccc}
\hline Lama Puasa & Mean (SD) & Median & Range \\
\hline Makanan & 8,7500 & 7,0000 & 11,00 \\
& $(3,48597)$ & & \\
Minuman & 12,5660 & 6,0000 & 12,00 \\
\hline
\end{tabular}


Tabel 4 Durasi Puasa Subjek Penelitian

\begin{tabular}{ccccc}
\hline Durasi (jam) & $\begin{array}{c}\text { Clear Water } \\
\mathbf{n = 5 2}\end{array}$ & $\begin{array}{c}\text { ASI } \\
\mathbf{n = 1 1}\end{array}$ & $\begin{array}{c}\text { Susu Formula } \\
\mathbf{n = 3 5}\end{array}$ & $\begin{array}{c}\text { Makanan Padat } \\
\mathbf{n = 5 2}\end{array}$ \\
\hline $1-2$ & & & & \\
$2-4$ & $7(13 \%)$ & & & \\
$4-6$ & $18(35 \%)$ & 10 & 13 & $20(39 \%)$ \\
$6-8$ & $13(25 \%)$ & 1 & 3 & $7(13 \%)$ \\
$8-10$ & $5(10 \%)$ & & 19 & $25(48 \%)$ \\
$>10$ & $9(17 \%)$ & & & \\
\hline
\end{tabular}

Pada penelitian ini terdapat $87 \%$ sampel yang menjalankan puasa melebihi waktu yang direkomendasikan. Dari keseluruhan sampel, hanya 11 sampel yang masih mengonsumsi ASI dan hampir semua sampel menjalankan puasa ASI sesuai dengan waktu yang diinstruksikan. Dari 52 orang sampel, terdapat 35 orang yang mengonsumsi susu formula dan sebagian besar pasien tersebut masih menjalankan puasa melebihi waktu yang ditentukan. Semua sampel telah mengonsumsi makanan padat dan sebagian besar sampel (62\%) tersebut menjalankan puasa melebihi waktu yang telah direkomendasikan (Tabel 4).

Sejumlah 43 orang dari keseluruhan sampel mendapatkan cairan infus sebelum dilakukan induksi anestesia, keadaan ini sesuai dengan jumlah sampel yang dirawat dan cairan yang diberikan adalah NS $1 / 4+$ D 5\% serta Ringer laktat (Tabel 5).

\section{Pembahasan}

Puasa preoperatif adalah salah satu hal yang harus dilakukan sebelum tindakan anestesia. ${ }^{4,5}$ Tujuan utamanya adalah mengurangi volume serta keasaman lambung yang pada akhirnya

Tabel 5 Penggunaan Cairan Intravena Subjek Penelitian

\begin{tabular}{lc}
\hline \multicolumn{1}{c}{ Jenis } & Jumlah Pasien \\
\hline NS $1 / 4+$ D $5 \%$ & 22 \\
RL & 21 \\
NaCl & 0 \\
Lainnya & 0 \\
\hline
\end{tabular}

mengurangi risiko aspirasi pulmonal. ${ }^{2}$ Pada praktik puasa preoperatif sering kali melebihi dari apa yang dianjurkan oleh ASA disebabkan oleh banyak hal.

Populasi pada penelitian ini adalah pasien pediatrik yang berusia 6 bulan hingga 6 tahun yang mengonsumsi makanan serta minuman yang berbeda. Pasien yang berusia di atas 2 tahun tidak lagi mengonsumsi ASI dan tidak semua pasien mengonsumsi susu formula, namun semua pasien mengonsumsi makanan padat. Perbedaan lamanya puasa didapatkan bervariasi dari jenis asupan yang dikonsumsi berdasarkan rekomendasi ASA.

Hubungan antara gula darah saat induksi dan lama puasa dianalisis mempergunakan Uji Spearman karena data-data berdistribusi tidak normal dan diperoleh nilai $p=0,042$ yang bermakna berdasarkan uji statistika $(p<0,05)$. Kejadian hipoglikemia tidak ditemukan pada penelitian ini, hal ini dapat disebabkan oleh sampel yang digunakan adalah pasien dengan kriteria ASA 1 dan 2 tanpa kelainan metabolik sehingga respons tubuh terhadap puasa masih baik untuk mempertahankan kadar glukosa darah sewaktu, di samping itu sebagian besar pasien mendapatkan cairan intravena yang mengandung gula saat dirawat.

Puasa dari minuman rata-rata $12,56( \pm 3,26)$ jam dengan rentang durasi mulai dari 2 jam hingga 15 jam. Pasien dalam sampel penelitian ini mengonsumsi air putih tanpa tambahan gula. Penelitian di India menunjukkan durasi puasa dari minuman 2-18,75 jam dengan rata-rata 9,25 $\pm 4,25$ jam. ${ }^{7}$ Pemberian minuman dua jam sebelum operasi merupakan tindakan 
yang aman dan menguntungkan.

Pada penelitian ini diperoleh bahwa durasi puasa makanan padat rata-rata pada pasien pediatrik preanestesi adalah $8,75 \pm 3,48$ jam dengan rentang waktu mulai dari 4 hingga 15 jam. Hasil serupa didapatkan dari penelitian di India yang melakukan penelitian terhadap pasien pediatrik sebelum dilakukan operasi elektif, didapatkan lama puasa 4 jam-18,75 jam $(11,25 \pm 3,5$ jam $)$ untuk durasi puasa dari makanan padat. ${ }^{7}$ Penelitian yang dikerjakan di Inggris terhadap 34 anak yang menjalani one day surgery (ODS) didapatkan $20 \%$ anak berpuasa hingga lebih dari 16 jam sebelum operasi. ${ }^{11}$ Hampir semua penelitian dan survei tentang puasa preoperatif mendapatkan durasi yang lebih panjang daripada pedoman puasa preoperatif yang direkomendasikan ASA. ${ }^{1}$ Walaupun sudah diupayakan kampanye pedoman puasa preoperatif kepada dokter anestesi, dokter bedah, dan perawat di bangsal, hal ini tetap masih sulit diubah. ${ }^{7}$

Pasien pada penelitian ini terdiri atas 43 orang yang dirawat serta 9 orang yang tidak dirawat. Empat puluh tiga pasien yang dirawat mendapat cairan intravena selama perawatan, di antaranya 22 orang mendapatkan cairan NS $1 / 4+$ D 5\% serta 21 orang mendapat cairan Ringer laktat (Rl). Hal ini dapat memengaruhi hasil pemeriksaan GDS saat induksi dan juga hemodinamik pasien dibanding dengan pasien yang tidak mendapat cairan tersebut karena kedua cairan tersebut dapat memengaruhi kadar gula darah pasien.

Gula darah sewaktu (GDS) rata-rata saat induksi anestesia pada semua pasien yang menjalani puasa preoperatif adalah 89,21 $( \pm 14,96) \mathrm{mg} / \mathrm{dL}$. Gula darah saat induksi terendah yang ditemukan pada seorang pasien dengan GDS $59 \mathrm{mg} / \mathrm{dL}$, dua orang dengan GDS $60 \mathrm{mg} / \mathrm{dL}$ dan mereka merupakan pasien ODS yang tidak mendapatkan cairan intravena sebelumnya. Temuan ini lebih tinggi daripada penelitian di India dengan GDS rata-rata $79,22( \pm 11,22) .^{7}$ Berdasarkan penelitian di Inggris didapatkan sebanyak $8,8 \%$ pasien yang mengalami hipoglikemia dengan GDS $<50 \mathrm{mg} / \mathrm{dL}$ dan GDS rata-rata 74,88 $( \pm 0,63)$ $\mathrm{mg} / \mathrm{dL}$ dengan lama puasa rata-rata selama 14
$( \pm 1,88)$ jam. $^{8}$ Hasil ini lebih rendah daripada yang didapatkan pada penelitian ini. Keadaan ini mungkin disebabkan sebagian besar pasien mendapatkan sejumlah cairan intravena NS $1 / 4+\mathrm{D} 5 \%$ dan Ringer laktat selama puasa.

Dari penelitian ini dapat direkomendasikan dibuat panduan pelaksanaan puasa preoperatif di RSHS sesuai dengan pedoman menurut ASA dan diberikan kepada pasien dan keluarganya dalam bentuk kartu ataupun brosur setelah pemberian edukasi pada saat visite preoperasi.

Perlu diperkirakan antara jadwal operasi yang tepat dan penyesuaian jadwal puasa preoperatif bila terjadi perubahan jadwal operasi akibat pembatalan atau keterlambatan mulai operasi sehingga pasien dapat dipuasakan sesuai aturan. Komunikasi yang efektif harus dilakukan antara dokter anestesi, dokter bedah, dan perawat di bangsal tentang penjadwalan ulang puasa bila terjadi keterlambatan.

Pemberian makan sebelum puasa dimulai harus direkomendasikan untuk dilaksanakan sesuai jadwal karena hal ini dapat menghindari puasa yang terlalu lama. Pemberian minum 2 jam sebelum operasi sebaiknya dilakukan, oleh karena hal tersebut terbukti aman serta menguntungkan. Pada pasien yang dirawat, pemberian cairan intravena yang mengandung glukosa sebaiknya dilakukan sejak pasien dipuasakan untuk mencegah hipoglikemia dan mencegah dehidrasi.

\section{Simpulan}

Berdasarkan hasil penelitian diatas didapatkan bahwa lama puasa preanestesia pada pasien pediatrik yang akan menjalani operasi elektif di Rumah Sakit Dr. Hasan Sadikin Bandung melebihi waktu yang direkomendasikan oleh ASA. Terdapat hubungan antara lama puasa preanestesi dan kadar gula darah saat induksi.

\section{Daftar Pustaka}

1. Arun BG, Korula G. Preoperative fasting in children: an audit and its implications in a tertiary care hospital. J Anesthesiol Clin Pharmacol. 2013;29(1):88-91.

2. Ludwig RB, Paludo J, Fernandes D, Scherer 
F. Lesser time of preoperative fasting and early postoperative feeding are safe? ABCD Arq Bras Cir Dig. 2013;26(1):54-8.

3. Kulshrestha M, Mathews JJ, Kapadia CM, Sanwatsarkar S. Breaking the midnight fast: an observational cross-sectional audit of preoperative fasting policies and practices at a tertiary care hospital. Indian J Anaesth. 2013;57(4):414-7.

4. CookDR. Hypoglycemia and hyperglycemia. Dalam: Atlee JL, penyunting. Complications in anesthesia. Edisi ke-2. Philadelphia: Saunders Elsivier; 2007. hlm. 657-8.

5. Kratzing C. Nutrition is the cutting edge in surgery: peri-operative feeding. Proceeding of the nutrition society. 2011 (diunduh 20 Juli 2014). Tersedia dari: www.journals.cambridge.org.

6. ASA. Practice guidelines for preoperative fasting and the use of pharmacologic agents to reduce the risk of pulmonary aspiration: application to healthy patients undergoing elective procedures. Anesthesiology.
2011;114(3):896-905.

7. Sharma V, Sharma R, Singh G, Gurkhoo $S$, Qazi S. Preoperative fasting duration and incidence of hypoglycemia and hemodynamic response in children. J Chem Pharm Res. 2011;3(6):382-91.

8. Engelhardt T. Are you hungry? are you thirsty? -fasting times in elective outpatient pediatric patients. Pediatr Anesth. 2011; 21:964-8.

9. Gunawardhana. Knowledge, attitudes and practice of preoperative fasting guidelines in the National Hospital of Sri Lanka. Sri Lanka J Anaesthesiol. 2012;20(2):1-4.

10. Aroni P, Nascimento LA, Fonseca LF. Assessment strategies for the management of thirst in the post anesthetic recovery room. Acta Paul Enferm. 2012;25(4):5306.

11. Gül A, Andsoy II, Üstündağ H, Özkaya BO. Assessment of preoperative fasting time in elective general surgery. JMHM. 2013;1(1):1-8. 